\title{
REALISASI KESANTUNAN BERBAHASA DALAM PROSES PEMBELAJARAN DI SEKOLAH MENENGAH ATAS KOTA BALIKPAPAN
}

\author{
Jannah Octavia Wulandari Naibahas ${ }^{1}$, Indah Ika Ratnawati ${ }^{2}$, Retnowaty ${ }^{3}$ \\ Universitas Balikpapan ${ }^{1}$, Universitas Balikpapan ${ }^{2}$, Universitas Balikpapan ${ }^{3}$ \\ pos-el: Jannah.octavia@gmail.com¹, indah.ika@uniba-bpn.ac.id², retnowaty@uniba-bpn.ac.id³
}

\begin{abstract}
ABSTRAK
Penelitian ini bertujuan untuk mendeskripsikan realisasi kesantunan dan wujud penyimpangan kesantunan berbahasa yang terjadi dalam proses pembelajaran di SMA Negeri 9 Balikpapan dalam hal pemilihan kata dan cara berbicara yang santun serta untuk mengetahui faktor-faktor penyebab kesantunan dan ketikdaksantunan berbahasa dalam proses pembelajaran. Jenis penelitian yang digunakan dalam penelitian ini adalah penelitian kualitatif dengan rancangan deskriptif dan pendekatan sosiopragmatik serta teori yang dikemukakan oleh Leech. Teknik yang digunakan dalam mengumpulkan data ialah teknik simak dengan teknik lanjutan simak bebas libat cakap, teknik rekam, dan teknik catat. Teknik yang digunakan untuk menganalisis data menggunakan metode Miles and Huberman. Hasil penelitian yang menunjukkan bahwa penyimpangan kesantunan berbahasa dalam proses pembelajaran di kelas XI SMA N 9 Balikpapan sebanyak 77 tuturan, sedangkan pematuhan sebanyak 8 tuturan. Di antara maksimmaksim kesantunan berbahasa, maksim yang paling banyak disimpang dalam proses pembelajaran adalah maksim kebijaksanaan, kedermawanan dan maksim penghargaan dengan faktor penyebab ketidaksantunan yang paling dominan terjadi ialah sengaja memojokkan mitra tutur dan kritik secara langsung dengan kata-kata kasar. Sementara itu, maksim yang paling banyak dipatuhi dalam proses pembelajaran adalah maksim kebijaksanaan dan maksim kedermawanan dengan faktor dominan penyebab kesantunan ialah memperhatikan cara menyampaikan dalam penggunaan ragam bahasa dan memperhatikan tujuan yang akan dicapai dalam berbicara.
\end{abstract}

Kata kunci : kesantunan, pembelajaran, sekolah menengah atas

\begin{abstract}
This study aims to describe the realization of politeness and the deviation of language politeness that occurs in the learning process at SMA Negeri 9 Balikpapan in terms of choosing words and speaking politely and to determine the factors that cause politeness and language politeness in the learning process. The type of research used in this research is qualitative research with a descriptive design and a sociopragmatic approach and the theory proposed by Leech. The technique used in collecting data is the listening technique with advanced techniques of free listening proficiently, recording techniques, and note-taking techniques. The technique used to analyze data using the Miles and Huberman method. The results showed that the deviation of language politeness in the learning process in class XI SMA N 9 Balikpapan was 77 utterances, while obedience was as many as 8 utterances. Among the maxim of politeness in language, the maxim that is most distorted in the learning process is the maxim of wisdom, generosity and the maxim of appreciation with the most dominant cause of impoliteness is deliberately cornering the speech partner and criticism directly with harsh words. Meanwhile, the maxims that are most widely adhered to in the learning process are the maxim of wisdom and the maxim of generosity with the dominant factor causing politeness is paying attention to how to convey in the use of various languages and paying attention to the goals to be achieved in speaking.
\end{abstract}

Keywords: politeness, learning, upper secondary school 


\section{PENDAHULUAN}

Dalam kehidupan sehari-hari, manusia pasti menggunakan bahasa untuk berinteraksi satu sama lain. Dalam berinteraksi, diperlukan aturan - aturan yang mengatur penutur dan lawan tutur dalam berbahasa agar nantinya dapat terjalin komunikasi yang baik di antara keduanya. Aturan - aturan tersebut terlihat pada prinsip kesantunan berbahasa yang dikemukakan oleh Leech (Chaer, 2010). Ia membagi prinsip kesantunan berbahasa menjadi enam, yakni maksim kebijaksanaan, maksim kedermawanan, maksim penghargaan, maksim kerendahan hati, maksim pemufakatan dan maksim simpati.

Dalam berbahasa, manusia perlu memperhatikan adanya kesantunan berbahasa ketika berkomunikasi dengan manusia lainnya. Hal itu bertujuan agar manusia bisa menggunakan bahasa yang santun dan tidak melakukan kesalahan dalam berbahasa. Sebuah tuturan dikatakan santun atau tidak, sangat tergantung pada ukuran kesantunan berbahasa yang dipakai oleh penutur. Tuturan dalam bahasa Indonesia secara umum sudah dianggap santun, jika penutur menggunakan kata - kata yang tuturannya tidak mengandung ejekan secara langsung, tidak memerintah secara langsung, serta menghormati orang lain. Oleh karena itu, kesantunan berbahasa ini perlu dikaji guna mengetahui seberapa banyak kesalahan atau penyimpangan dan pematuhan kesantunan berbahasa ketika berkomunikasi antara satu sama lain.

Kesalahan berbahasa sering terjadi dalam proses komunikasi dan interaksi antara individu satu dengan lainnya. Interaksi itu dapat terjadi pada forum-forum resmi ataupun tidak resmi. Sekolah sebagai tempat pendidikan pada forum resmi, ternyata kesalahan dalam kesantunan berbahasa masih sering ditemukan. Hal itu bisa diamati dalam proses belajar mengajar, maupun kegiatan di lingkungan sekolah.

Dalam berkomunikasi dengan orang lain, kesantunan berbahasa merupakan aspek yang sangat penting untuk membentuk karakter dan sikap seseorang. Melalui penggunaan bahasa, seseorang dapat mencerminkan karakter dan kepribadian orang tersebut, untuk mengembangkan karakter dan sikap seseorang prinsip kesantunan berbahasa dapat diimplikasikan sebagai materi pendidikan karakter dalam proses pembelajaran.

Fokus penelitian ini adalah SMA Negeri 9 dan kelas XI, karena dari hasil pengamatan yang telah peneliti lakukan, pada saat kegiatan belajar mengajar berlangsung sering ditemui kesalahan-kesalahan dalam berbahasa siswa. Dalam berkomunikasi, umumnya ada yang memperhatikan aspek kesantunan berbahasa tetapi ada juga yang tidak. Berdasarkan observasi awal yang dilakukan peneliti di SMA Negeri 9 Balikpapan terutama di kelas XI, dapat disimpulkan bahwa pada saat melakukan kegiatan belajar mengajar terlihat adanya beberapa kesalahan dalam pemilihan kata dan ketidaktahuan tata cara berbicara yang santun. Misalnya, pada saat proses pembelajaran berlangsung dengan materi berdiskusi siswa terkadang melanggar kesantunan dalam bertutur.

Tuturan yang dipakai terkadang berupa sindiran, ejekan, atau bantahan yang dapat menyinggung perasaan orang lain. Selain itu, bahasa yang kurang santun terjadi dikarenakan siswa masih berada dalam usia remaja yang sedang berproses dalam membentuk karakter dan jati dirinya. Pada usia-usia ini, anak mudah terpengaruh dengan munculnya bahasa - bahasa gaul yang dapat mempengaruhi gaya bicara dalam proses kegiatan belajar mengajar. Tujuan penelitian ini yaitu 1) mendeskripsikan realisasi kesantunan dan wujud penyimpangan kesantunan berbahasa dalam proses 
pembelajaran di sekolah menengah atas kota Balikpapan; 2) mengetahui faktor-faktor penyebab kesantunan dan ketidaksantunan berbahasa dalam proses pembelajaran di sekolah menengah atas kota Balikpapan. Oleh karena itu, peneliti tertarik akan menganalisis tentang "Realisasi Kesantunan Berbahasa Dalam Proses Pembelajaran Di Sekolah Menengah Atas Kota Balikpapan ".

Beberapa teori digunakan dalam penelitian ini. Menurut Rahardi (2005 : 35), penelitian kesantunan mengkaji penggunaan bahasa (language use) dalam suatu masyarakat bahasa tertentu. Masyarakat tutur yang dimaksud adalah masyarakat dengan aneka latar belakang situasi sosial dan budaya yang mewadahinya. Adapun yang dikaji di dalam penelitian kesantunan adalah segi maksud dan fungsi tuturan. Sedangkan Leech (Chaer, 2010 : 56) menjelaskan bahwa kesantunan berbahasa pada dasarnya harus memperhatikan enam maksim kesantunan. Dengan menerapkan maksim kesantunan, penutur tidak akan menggunakan tuturan tuturan yang merendahkan mitra tutur sehingga komunikasi akan berjalan dalam situasi yang kondusif. Dari beberapa pendapat ahli yang telah dipaparkan, dapat disimpulkan bahwa kesantunan berbahasa dapat dilakukan dengan cara pelaku tutur mematuhi prinsip kesantunan berbahasa yang berlaku di masyarakat pemakai bahasa tersebut. Jadi, diharapkan pelaku tutur dalam bertutur dengan mitra tuturnya untuk tidak mengabaikan prinsip kesantunan berbahasa. Dalam hal ini untuk menjaga hubungan baik dengan mitra tuturnya.

Wijana (Oktafiana, 2012 : 4) mengungkapkan bahwa retorika interpersonal, pragmatik membutuhkan prinsip kesantunan (politeness principle). Prinsip kesantunan ini berhubungan dengan dua peserta percakapan, yakni diri sendiri (self) dan orang lain (other). Diri sendiri adalah penutur, dan orang lain adalah lawan tutur, serta orang ketiga yang dibicarakan penutur dan lawan tutur.

Senada dengan Wijana, menurut Leech (Rahardi, 2005:60-66) dalam bertindak tutur yang santun, agar pesan dapat disampikan dengan baik pada peserta tutur, komunikasi yang terjadi perlu mempertimbangkan prinsip - prinsip kesantunan berbahasa. Prinsip kesantunan berbahasa yang dikemukakan oleh Leech (Rahardi, 2005 : 60 - 65), yakni sebagai berikut.

a. Maksim Kebijaksanaan

Leech

(Rahardi,2005:60)

mengungkapkan gagasan dasar maksim kebijaksanaan dalam prinsip kesantunan adalah bahwa para peserta pertuturan hendaknya berpegangan pada prinsip untuk selalu mengurangi keuntungan dirinya sendiri dan memaksimalkan keuntungan pihak lain dalam kegiatan bertutur.

b. Maksim Kedermawanan

Leech (Rahardi,2005:61) mengatakan bahwa dengan maksim kedermawanan atau maksim kemurahan hati, para peserta pertuturan diharapkan dapat menghormati orang lain.

c. Maksim Penghargaan

Leech (Rahardi,2005:63) mengungkapkan bahwa dalam maksim penghargaan dijelaskan bahwa orang akan dapat dianggap santun apabila dalam bertutur selalu berusaha memberikan penghargaan kepada pihak lain. Maksim Kesederhanaan

d. Leech (Rahardi, 2005:64) mengatakan bahwa di dalam maksim kesederhanaan atau maksim kerendahan hati, peserta tutur diharapkan dapat bersikap rendah hati 
dengan cara mengurangi pujian terhadap dirinya sendiri.

e. Maksim Pemufakatan

Leech (Rahardi, 2005 : 64) menyatakan dalam maksim ini, menekankan agar para peserta tutur dapat saling membina kecocokan atau kemufakatan di dalam kegiatan bertutur.

f. Maksim Kesimpatian

Lecch (Rahardi, 2005:65) menyatakan di dalam maksim ini diharapkan agar para peserta tutur dapat memaksimalkan sikap simpati antara pihak yang satu dengan pihak yang lainnya.

Untuk dapat memahami dan menguasai berbahasa secara santun, Pranomo (Chaer,2010:69) menyebutkan adanya beberapa faktor atau hal yang menyebabkan sebuah pertuturan itu menjadi tidak santun. Penyebab ketidaksantunan itu antara lain :

1) Kritik secara langsung dengan katakata kasar

2) Dorongan rasa emosi penutur

3) Protektif terhadap pendapat

4) Sengaja menuduh lawan tutur

5) Sengaja memojokkan mitra tutur Pranomo (Chaer, 2010:62) menguraikan halhal yang perlu di perhatikan agar komunikasi dapat berhasil, yakni sebagai berikut.

1) Perhatikan situasinya

2) Perhatikan mitra tuturnya

3) Perhatikan pesan yang disampaikan

4) Perhatikan tujuan yang hendak dicapai

5) Perhatikan cara menyampaikan

6) Perhatikan ragam bahasa yang digunakan

7) Hindari pujian untuk diri sendiri

8) Berikan keuntungan pada mitra tutur

9) Berikan pujian pada mitra tutur

10) Buatlah kesepahaman dengan mitra tutur.
Menurut Usman (Nathanael, dkk, 2013:186), pembelajaran adalah inti dari proses pendidikan secara keseluruhan dengan guru sebagai pemegang peranan utama. Pembelajaran merupakan suatu proses yang mengandung serangkaian perbuatan guru dan siswa atas dasar hubungan timbal balik yang berlangsung dalam situasi edukatif untuk mencapai tujuan tertentu.

Penelitian serupa pernah dilakukan oleh Riyanto (2013) dengan judul “ Realisasi Kesantunan Berbahasa pada Percakapan Siswa dengan Guru di SMA Muhammadiyah 3 Surakarta", Penelitian selanjutnya pernah dilakukan oleh Rosanti, dkk (2015) dengan judul "Realisasi Kesantunan Berbahasa Guru dan Siswa Kelas VII A SMP Negeri 2 Sungai Pinyuh". Sedangkan Umamah (2015) melakukan penelitian dengan judul “ Realisasi Kesantunan Berbahasa di Kalangan Santri Putri dalam Berinteraksi dengan Masyarakat Pesantren di Ponpes Al Ma'un Sroyo Karanganyar". Penelitian serupa berikutnya dilakukan oleh Retnowaty (2015) dengan judul "Politeness Strategies Used by Colter Stevens as the Main Character in Source Code Movie".

Perbedaan penelitian di atas adalah penelitian Riyanto lebih menekankan pada percakapan siswa dengan guru di lingkungan sekolah, sedangkan Rosanti dkk lebih menekankan pada realisasi kesantunan berbahasa guru dengan siswa di kelas VII A dan Umamah penelitiannya berfokus pada interaksi antara kalangan santri putri dengan masyarakat pesantren, berbeda dengan penelitian peneliti lebih menekankan pada Realisasi Kesantunan Berbahasa dalam Proses Pembelajaran Bahasa Indonesia di kelas XI. Serta Retnowaty menggunakan teori kesantunan yang berbeda yakni Brown dan Levinson (1987) yang terkait strategi kesantunan. Persamaan keempat penelitian di atas dengan penelitian ini adalah sama - sama 
meneliti tentang kesantunan beserta maksimmaksimnya, sedangkan perbedaannya adalah unsur yang dikaji, teori, dan subjek yang dikaji.

\section{METODE PENELITIAN}

Jenis penelitian yang digunakan adalah penelitian kualitatif. Sedangkan rancangan penelitian yang digunakan bersifat deskriptif. Pendekatan yang peneliti gunakan adalah pendekatan sosiopragmatik, pendekatan sosiopragmatik adalah telaah mengenai kondisi - kondisi setempat atau lokal yang lebih khusus mengenai penggunaan bahasa dalam konteks sosial dan konteks kultural tertentu.

Data dalam penelitian ini berupa tuturan dalam interaksi siswa dengan siswa, maupun siswa dengan guru kelas XI selama proses pembelajaran berlangsung di SMA Negeri 9 Balikpapan yang mengandung kesantunan berbahasa. Sumber data dalam penelitian ini adalah siswa - siswi kelas XI SMA Negeri 9 Balikpapan.

Instrumen penelitian ini adalah peneliti sendiri. Sugiyono (2012:306) mengemukakan bahwa penelitian kualitatif sebagai human instrument, berfungsi menetapkan fokus penelitian, memilih informan sebagai sumber data, melakukan pengumpulan data, menilai kualitas data, menafsirkan data dan membuat kesimpulan atas semuanya. Selain peneliti sebagai instrumen penelitian, peneliti melengkapi data dengan instrumen penunjang, yaitu kamera, alat tulis, catatan lapangan dan kartu data.

Metode yang digunakan peneliti dalam teknik pengumpulan data adalah metode "Simak" dengan teknik lanjut
Simak Bebas Libat Cakap (SBLC), Rekam dan Catat (Mahsun, 2005).

Teknik analisis data yang digunakan dalam penelitian ini adalah Model Miles and Huberman (Sugiyono, 2012:337) menggunakan langkah - langkah sebagai berikut.

1) Reduksi data (Data Reduction) Dalam hal ini, peneliti merangkum percakapan antara siswa dengan siswa, maupun siswa dengan guru yang telah ditulis. Dari percakapan tersebut tentu menemukan pematuhan dan penyimpangan maksim kesantunan berbahasa yang kemudian disusun secara sistematis sehingga menemukan kata-kata yang paling sering digunakan oleh siswa dengan siswa, maupun siswa dengan guru selama proses pembelajaran berlangsung yang dianggap mematuhi dan menyimpang dari maksim kesantunan berbahasa menurut Leech.

2) Display Data

Display data adalah pendeskripsian sekumpulan informasi tersusun yang memberikan kemungkinan adanya penarikan kesimpulan dan pengambilan tindakan.

3) Verifikasi dan penegasan kesimpulan (conclusion affimation dan verification)

Merupakan kegiatan akhir dari analisis data. Penarikan kesimpulan berupa kegiatan interpretasi, yaitu menemukan makna data yang telah disajikan.

\section{HASIL DAN PEMBAHASAN}

Berdasarkan data yang diperoleh dalam penelitian, ditemukan realisasi penyimpangan dan pematuhan prinsip 
kesantunan berbahasa. Keseluruhan data yang terkumpul berdasarkan jumlah kartu data yakni 85 kartu data tuturan. Kartu data yang berupa penyimpangan prinsip kesantunan berbahasa berjumlah 77 data, sedangkan yang berupa pematuhan prinsip kesantunan berbahasa berjumlah 8 data.

\section{Realisasi Penyimpangan Prinsip Kesantunan Berbahasa dalam Proses Pembelajaran}

Berdasarkan hasil penelitian, jumlah penyimpangan prinsip kesantunan berbahasa dalam proses pembelajaran berjumlah 77 data tuturan. Data penyimpangan prinsip kesantunan berbahasa terdiri dari enam maksim yaitu maksim kebijaksanaan, maksim kedermawanan, maksim penghargaan, maksim kesederhanaan, maksim permufakatan dan maksim kesimpatian.

Penyimpangan prinsip kesantunan berbahasa berupa penyimpangan satu maksim dan dua maksim sekaligus dalam satu tuturan. Penyimpangan dua maksim terdiri atas penyimpangan maksim kebijaksanaan dan kedermawanan, maksim kebijaksanaan dan penghargaan, maksim kebijaksanaan dan kesimpatian, maksim penghargaan dan permufakatan. Hasil penelitian tersebut disajikan dalam bentuk tabel sebagai berikut.

Tabel.1 Realisasi Penyimpangan Prinsip

Kesantunan Berbahasa dalam Proses

Pembelajaran

\begin{tabular}{|c|c|c|c|c|c|c|c|c|c|c|}
\hline \multirow{3}{*}{ KONTEKS } & \multicolumn{10}{|c|}{ PENYIMPANGAN } \\
\hline & \multicolumn{6}{|c|}{$\begin{array}{c}\text { SATU } \\
\text { MAKSIM }\end{array}$} & \multicolumn{4}{|c|}{$\begin{array}{c}\text { DUA } \\
\text { MAKSIM }\end{array}$} \\
\hline & a & b & c & d & e & f & $a \& b$ & $a \& c$ & $a \& f$ & c\&e \\
\hline 1 & 6 & - & 1 & - & 1 & 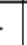 & - & - & 1 & - \\
\hline 2 & 3 & - & 1 & -1 & 1 & - & - & - & - & - \\
\hline 3 & 18 & 11 & 13 & & 7 & 1 & 3 & 4 & - & 3 \\
\hline JUMLAH & & & & & & & & & & 11 \\
\hline
\end{tabular}

Berdasarkan data tersebut menunjukkan bahwa dalam proses pembelajaran yang terdiri dari tiga konteks yaitu konteks pertama sebelum pembelajaran dimulai, konteks kedua pada saat diskusi, dan konteks yang ketiga pada saat sesi tanya jawab berlangsung, secara keseluruhan ditemukan 77 data tuturan yang menyimpang dari prinsip kesantunan berbahasa. Pada tiap-tiap konteks, terjadi penyimpangan realisasi kesantunan berbahasa yang dilakukan oleh peserta didik dalam kegiatan proses pembelajaran, yang paling banyak menyimpang dari kesantunan berbahasa ialah konteks sesi tanya jawab, pada konteks sesi tanya jawab terdapat 66 penyimpangan satu maksim dan 11 penyimpangan dua maksim.

Dari 77 data tuturan yang menyimpang, pada data satu maksim yang banyak dilanggar adalah maksim kebijaksanaan sebanyak 27 kesalahan dan pada data dua maksim yang banyak dilanggar ialah maksim kebijaksanaan dan maksim penghargaan sebanyak 4 kesalahan. Dari data tersebut menunjukkan bahwa ketiga konteks yang terjadi dalam proses pembelajaran, penyimpangan prinsip kesantunan berbahasa paling banyak muncul pada konteks sesi tanya jawab karena pada saat sesi tanya jawab banyak peserta didik yang tidak bisa menggunakan bahasa santun saat bertanya, memberikan kritik yang dapat menjatuhkan orang lain, tidak menghormati lawan tutur ketika sedang berbicara, tidak memberikan kesempatan pada lawan tutur untuk berpendapat, tidak mengucapkan "terima kasih" ketika mendapat saran atau kritik, memaksakan kehendak dalam berbicara, tidak memberikan pilihan kepada lawan tutur, berbicara tidak sesuai situasi atau pokok permasalahan yang sedang dibicarakan, tidak ada kesepakatan antara penutur dan lawan tutur dalam berbicara, serta tidak memberikan rasa simpati yang tulus kepada lawan tutur.

\section{Penyimpangan Satu Maksim (Maksim Penghargaan )}

Maksim penghargaan menjelaskan bahwa orang akan dianggap santun apabila dalam bertutur selalu berusaha memberikan penghargaan kepada pihak 
lain. Data yang termasuk dalam penyimpangan maksim penghargaan dijabarkan sebagai berikut.

(1) Ir : saya akan mempresentasikan makalah saya tentang “ pemanfaatan buah naga"

Iw : apa!!!

An : buah naga

Iw : buah naga sekilo 5000 hahaha , (lanjut lagi dengan mengejek) di karang anyar 2500 haha

Ir : (mempresentasikan makalahnya yang berjudul "pemanfaatan buah naga)

Al : (menegur Ir yang lama mempresentasikan makalahnya di depan kelas) Irwan lama weeh

Gs : (menyuruh kelompok Ayu yang bertanya) ya, kelompoknya Ayu ke sana pertanyaan.

(No Data.17.01)

Konteks tuturan tersebut diucapkan oleh seorang siswa berjenis kelamin lakilaki yang sedang mengikuti proses pembelajaran di kelas XI IPS 1 dengan materi melaporkan hasil penelitian mata pelajaran bahasa Indonesia. Ketika itu Ir akan mempresentasikan makalahnya yang berjudul "pemanfaatan buah naga", saat Ir memberitahukan kepada Ss judul yang akan dibahasnya Iw langsung berkata "apa" seakan-akan ia sengaja tidak mendengar tentang apa yang telah diberitahukan oleh Ir. An menjawab "buah naga" untuk memberitahukan Iw, Iw langsung mengejek judul Ir dengan "buah naga sekilo 5000 hahaha, di karang anyar 2500 haha", An ikut tertawa ketika Iw mengejek Ir. Ir langsung mempresentasikan makalahnya ia hanya terdiam ketika Iw mengejeknya seperti itu. Saat Ir mempresentasikan makalahnya Al mengomentari Ir karena ia lama menjelaskan sehingga bel istirahat sudah berbunyi, kemudian Gs langsung menyuruh kelompok Ay yang bertanya kepada Ir tentang makalah yang telah ia jelaskan.

Tuturan yang diucapkan oleh penutur Iw menunjukkan proses komunikasi yang menyimpang maksim penghargaan, karena penutur Iw dalam berbicara tidak menghargai, dan merendahkan lawan tuturnya dengan berkata yang menyakiti hati. Hal ini, terdengar pada tuturan penutur Iw "buah naga sekilo $\mathbf{5 0 0 0}$ hahaha, di karang anyar 2500 hahaha" dengan nada mengejek, saat lawan tutur Ir akan mempresentasikan makalahnya di depan kelas dengan judul "manfaat buah naga". Seharusnya penutur Iw dalam berbicara dapat memberikan penghargaan kepada lawan tutur Ir yaitu dengan tidak saling mengejek dan merendahkan pihak lain dalam kegiatan berbicara. Selain itu, faktor penyebab ketidaksantunan ialah penutur Iw sengaja memojokkan lawan tuturnya Ir, sehingga tuturan yang disampaikan oleh penutur Iw menjadikan lawan tutur Ir tidak dapat melakukan pembelaan.

\section{Penyimpangan Dua Maksim (Maksim Kebijaksanaan dan Kedermawanan)}

Bentuk penyimpangan maksim kebijaksanaan dan kedermawanan dapat dilihat dalam data berikut.

(2) $\mathrm{Rg}$ : bagaimana cara mengelola daun sirih dalam bidang perindustrian? Ini susah soalnya ga ada di internet jadi gini aja

Hr : itu logika cas

Rg : Pabrik

$\mathrm{Hr}$ : misalnya jadi odol fitnah

Oc : bukan itu pembersih itunah

$\mathrm{Hr}$ : buat sikat gigi, keputihan kiranti seperti itu, eh jangan sebut merek tiiit.....

$\mathrm{Rg}$ : ee, di buat pabrik ayah

$\mathrm{Hr}$ : dibuat pabrik hahaha

\section{Aj : bodoknya eh}

(No Data.68.02)

Konteks tuturan tersebut diucapkan oleh seorang siswi berjenis kelamin perempuan yang sedang mengikuti proses pembelajaran di kelas XI IPS 2 dengan materi melaporkan hasil penelitian mata pelajaran bahasa Indonesia. Ketika itu $\mathrm{Rg}$ sedang menjelaskan pertanyaan dari 
temannya Kh yaitu tentang cara mengelola daun sirih dalam bidang perindustrian, $\mathrm{Rg}$ berkata kepada temannya bahwa soal ini susah dan tidak ada di internet, $\mathrm{Hr}$ langsung berkata "itu logika ces", Rg kembali menjawab "pabrik". $\mathrm{Hr}$ memberikan contoh kepada $\mathrm{Rg}$ agar ia mudah paham "misalnya jadi odol gitu nah", Oc pun ikut menjawab "bukan itu pembersih itu nah", $\mathrm{Hr}$ memberikan contoh kembali "buat sikat gigi, keputihan kiranti seperti itu, eh jangan sebut merek tiit..." Rg langsung menjawab "ee di buat pabrik yah" $\mathrm{Hr}$ tertawa mendengar jawaban dari Rg, kemudian Aj langsung berkata kepada Rg "bodoknya eh" karena Rg tidak bisa menjawab.

Tuturan yang diucapkan oleh penutur $\mathrm{Hr}$ dan $\mathrm{Aj}$ menunjukkan proses komunikasi yang menyimpang maksim kebijaksanaan dan kedermawanan karena tuturan penutur $\mathrm{Hr}$ dan $\mathrm{Aj}$ menggunakan diksi yang kasar ketika berbicara dengan Rg yaitu "ces" dan "bodok" serta tidak menghormati $\operatorname{Rg}$ sebagai lawan tutur. Dalam maksim kebijaksanaan diharapkan penutur dapat mengurangi keuntungan diri sendiri dan memaksimalkan keuntungan pihak lain, namun pada tuturan penutur $\mathrm{Hr}$ dan $\mathrm{Aj}$ tidak dapat memaksimalkan keuntungan pihak lain yaitu lawan tutur $\mathrm{Rg}$ dalam kegiatan bertutur karena penutur $\mathrm{Hr}$ dan $\mathrm{Aj}$ menggunakan diksi yang kasar untuk menegur $\mathrm{Rg}$ yang tidak bisa menjawab pertanyaan dari temannya. Dalam skala keuntungan kerugian, semakin tuturan itu menguntungkan diri penutur akan dianggap tidak santunlah tuturan itu. Sedangkan dalam maksim kedermawanan atau kemurahan hati, para peserta pertuturan diharapkan dapat menghormati orang lain, tidak dengan tuturan penutur $\mathrm{Aj}$ ia tidak dapat menghormati lawan tutur Rg ketika dalam proses diskusi tanya jawab, saat itu lawan tutur Rg tidak dapat menjawab pertanyaan dari temannya, penutur $\mathrm{Aj}$ langsung berkata "bodoknya eh" kepada lawan tutur $\mathrm{Rg}$ karena ia tidak bisa menjawab pertanyaan temannya. Selain itu penyebab ketidaksantunan ialah penutur sengaja memojokkan lawan tuturnya dalam berbicara, dengan ini tuturan yang disampaikan penutur $\mathrm{Hr}$ dan $\mathrm{Aj}$ membuat lawan tutur $\mathrm{Rg}$ tidak dapat melakukan pembelaan.

\section{Realisasi Pematuhan Kesantunan Berbahasa dalam Proses Pembelajaran}

Pematuhan prinsip kesantunan berbahasa terdiri dari enam maksim yaitu maksim kebijaksanaan, maksim kedermawanan, maksim penghargaan, maksim kesederhanaan, maksim permufakatan dan maksim kesimpatian yang ditemukan dalam proses pembelajaran yang terdiri dari tiga konteks yaitu konteks pertama sebelum pembelajaran dimulai, konteks kedua pada saat diskusi dan konteks ketiga pada saat sesi tanya jawab berlangsung, secara keseluruhan ditemukan 8 data tuturan pematuhan dari prinsip kesantunan berbahasa.

Data pematuhan prinsip kesantunan tersebut berupa satu maksim yaitu maksim kebijaksanaan dan maksim kedermawanan, terdapat pula pematuhan dua maksim yaitu maksim kedermawanan dan maksim permufakatan, serta pematuhan tiga maksim yaitu maksim kedermawanan, maksim permufakatan, dan maksim penghargaan pada satu konteks. Dalam penelitian ini tidak ditemukan adanya pematuhan maksim kesederhanaan dan maksim kesimpatian. Pematuhan prinsip kesantunan ini berupa pematuhan satu maksim, dua maksim dan tiga maksim. Berikut ditampilkan tabel hasil penelitian pematuhan prinsip kesantunan berbahasa.

Tabel. 2 Realisasi Pematuhan Prinsip

Kesantunan Berbahasa dalam Proses Pembelajaran

\begin{tabular}{|c|c|c|c|c|c|c|c|c|}
\hline \multirow{4}{*}{ KONTEKS } & \multicolumn{8}{|c|}{ PEMATUHAN } \\
\hline & \multirow{2}{*}{\multicolumn{6}{|c|}{$\begin{array}{c}\text { SATU } \\
\text { MAKSIM }\end{array}$}} & \multirow{3}{*}{$\begin{array}{c}\begin{array}{c}\text { DUA } \\
\text { MAKSIM }\end{array} \\
\mathrm{b} \& \mathrm{e}\end{array}$} & \multirow{3}{*}{$\begin{array}{c}\text { TIGA } \\
\text { MAKSIM } \\
\text { b \& c \& e }\end{array}$} \\
\hline & & & & & & & & \\
\hline & $\mathrm{a}$ & $\mathrm{b}$ & $\mathrm{c}$ & $\mathrm{d}$ & $\mathrm{e}$ & $\mathrm{f}$ & & \\
\hline 1 & 1 & - & - & - & - & - & - & - \\
\hline 2 & 1 & - & - & - & - & - & 1 & 2 \\
\hline 3 & 2 & 1 & - & - & - & - & - & - \\
\hline \multirow{2}{*}{ JUMLAH } & & & & & & & & 8 \\
\hline & & & & & & & & TOTAL \\
\hline
\end{tabular}


Berdasarkan data tersebut menunjukkan bahwa dalam proses pembelajaran yang terdiri dari tiga konteks yaitu konteks pertama sebelum pembelajaran dimulai, konteks kedua pada saat diskusi, dan konteks ketiga pada saat sesi tanya jawab berlangsung, secara keseluruhan terdapat 8 tuturan yang mematuhi prinsip kesantunan berbahasa. Pada tiap - tiap konteks, peserta didik melakukan pematuhan kesantunan berbahasa, yang paling banyak mematuhi dari kesantunan berbahasa ialah konteks sesi tanya jawab berlangsung dan pada saat sesi diskusi, pada konteks sesi tanya jawab terdapat 2 pematuhan satu maksim dan pada saat sesi diskusi terdapat 2 pematuhan tiga maksim. Dari 8 data tuturan pematuhan maksim tersebut, pada data satu maksim yang paling banyak dipatuhi adalah maksim kebijaksanaan sebanyak 2 pematuhan, pada data tiga maksim yang banyak dipatuhi ialah maksim kedermawanan, maksim penghargaan dan maksim permufakatan sebanyak 2 pematuhan.

Dari data tersebut menunjukkan bahwa ketiga konteks yang terjadi dalam proses pembelajaran, pematuhan prinsip kesantunan berbahasa paling banyak muncul pada konteks sesi tanya jawab dan pada saat sesi diskusi karena pada saat sesi tanya jawab dan diskusi peserta didik, guru menggunakan kata "maaf" ketika terlambat masuk kelas, menegur dengan tuturan secara tidak langsung, memberikan kesempatan kepada lawan tutur untuk berpendapat, mengucapkan "terima kasih" ketika penutur telah memberikan jawaban atas pertanyaan dari lawan tutur, dan terjadinya kesepakatan atau kecocokan antara penutur dan lawan tutur dalam kegiatan diskusi dan tanya jawab selama proses pembelajaran berlangsung.

\section{Pematuhan Satu Maksim (Maksim Kebijaksanaan)}

Dalam maksim kebijaksanaan ini, penutur hendaknya selalu mengurangi keuntungan dirinya sendiri dan memaksimalkan keuntungan pada pihak lain dalam bertutur. Pada saat akan berbicara dengan orang lain, penutur harus bersikap santun, bijaksana, tidak memberatkan lawan tutur, dan menggunakan diksi yang halus dalam bertutur. Pematuhan maksim kebijaksanaan ini ditandai dengan pemilihan kata atau diksi yang tepat dalam bertanya, memerintah secara tidak langsung, menegur secara tidak langsung. Misalnya menggunakan kata maaf, saya, silahkan, mohon dan tolong. Pematuhan maksim kebijaksanaan ditunjukkan pada data berikut.

(3) $\mathrm{Hn}$

: eh kamu ga mau dengarin kah, assalamualaikum wr.wb

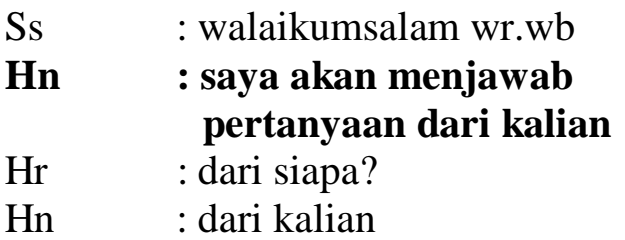

(No Data. 28.02)

Konteks tuturan tersebut diucapkan oleh seorang siswi berjenis kelamin perempuan yang sedang mengikuti proses pembelajaran di kelas XI IPS 2 dengan materi melaporkan hasil penelitian mata pelajaran bahasa Indonesia. Ketika itu Hn akan menjelaskan jawaban dari pertanyaan teman-temannya, saat $\mathrm{Hn}$ ingin menjelaskan Ss ribuk dan $\mathrm{Hn}$ menegur mereka " eh kamu ga mau dengarinkan" Ss terdiam dan mendengarkan $\mathrm{Hn}$ untuk menjelaskan jawaban dari pertanyaan teman-temannya. Hn membuka presentasinya dengan mengucapkan salam dan berkata " saya akan menjawab pertanyaan dari kalian", $\mathrm{Hr}$ bertanya "dari siapa" kemudian Hn menjawab "dari kalian".

Tuturan yang diucapkan oleh penutur Hn menunjukkan proses komunikasi yang termasuk dalam pematuhan maksim kebijaksanaan karena tutran penutur $\mathrm{Hn}$ memaksimalakan keuntungan pada lawan tutur dengan menggunakan diksi yang halus ketika Hn akan memulai presentasinya dengan tuturan "saya akan 
menjawab pertanyaan dari kalian”. Dalam maksim kebijaksanaan diharapkan penutur dapat mengurangi keuntungan diri sendiri dan memaksimalkan keuntungan pihak lain dalam kegiatan bertutur. Selain itu, faktor penyebab kesantunan ialah memperhatikan ragam bahasa yang digunakan, dalam hal ini penutur $\mathrm{Hn}$ menggunakan ragam bahasa yang halus yaitu menggunakan pilihan kata yang tepat ketika berbicara kepada lawan tutur, kemudian penutur Hn juga memperhatikan cara penyampaian dalam berbahasa ketika akan menjelaskan suatu topik kepada lawan tutur.

\section{Pematuhan Dua Maksim (Maksim Kedermawanan dan Maksim Permufakatan)}

Bentuk pematuhan maksim kedermawanan dan maksim permufakatan dapat dilihat dalam data berikut.

(4) Gs

: kulit kunyit setelah dicabut lalu bersihkan, lalu iris tipis-tipis direbus, begitu?

$\mathrm{Hn} \quad$ : iya bu

Gs : baru disaring supaya pasirnya, baru diminum. Sebaiknya dicampur dengan madu. Baik pertanyaan berikutnya dengarin yaaa Thamri....

$\mathrm{Hr} \quad$ : Thamri (memanggil Tm untuk mendengarkan jawaban dari Hn dan Gs)

Hn : pertanyaan dari An, Apakah khasiat kunyit putih?

1. Mengusir kanker

2. Mengobati batuk darah

3. Keracunan

4. Sela kanker ringan

5. Biasa dijadikan obat diare

\section{Hn : jelaskan? \\ Ss : jelas}

(No Data.30.02)

Konteks tuturan tersebut diucapkan oleh siswi berjenis kelamin perempuan yang sedang mengikuti proses pembelajaran di kelas XI IPS 2 dengan materi melaporkan hasil penelitian mata pelajaran bahasa Indonesia. Ketika itu Gs membantu Hn untuk menjelaskan bagaimana cara mengelola kunyit putih untuk pengobatan. Selama Hn menjelaskan dan dibantu oleh Gs, namun siswa bernama Tm tidak mendengarkannya, Gs langsung menegur Tm dengan kata-kata seperti "baik pertanyaan berikutnya dengarin yaaa Thamri”. Hr memanggil Tm untuk mendengarkan jawaban yang dijelaskan oleh Hn dan Gs, kemudian Hn melanjutkan menjelaskan jawaban dari pertanyaan An. Setalah Hn menjelaskan Hn bertanya kepada Ss "jelaskan" dan Ss menjawab "jelas" atas jawaban yang telah diberikan oleh Hn.

Tuturan yang diucapkan oleh penutur Hn dan lawan tutur Ss menunjukkan proses komunikasi yang mematuhi maksim kedermawanan dan maksim permufakatan karena tuturan penutur $\mathrm{Hn}$ dapat memaksimalkan keuntungan pihak lain dengan memberikan kesempatan kepada lawan tutur untuk bertanya dan lawan tutur bisa membina kecocokan di antara mereka dalam kegiatan bertutur saat diskusi sedang berlangsung di kelas. Pematuhan maksim kedermawanan ditunjukkan dengan penutur memberikan kesempatan kepada lawan tutur, seperti kata "jelaskan" dengan nada bertanya. Sementara itu, pematuhan maksim permufakatan ditunjukkan dengan tuturan "jelas". Tuturan tersebut memperlihatkan bahwa lawan tutur mampu membina kecocokan dengan penutur sehingga lawan tutur menerima hasil diskusi tersebut dengan baik. Selain itu faktor penyebab kesantunan berbahasa ialah memberikan keuntungan pada mitra tutur karena memberikan kesempatan kepada lawan tutur untuk bertanya, serta penutur $\mathrm{Hn}$ memperhatikan tujuan yang hendak dicapai yaitu membuat lawan tutur Ss paham akan penjelasan yang telah ia berikan. 


\section{Pematuhan Tiga Maksim Kedermawanan, Permufakatan Penghargaan) dan}

Bentuk pematuhan

(Maksim Maksim Maksim kedermawanan, maksim permufakatan, dan maksim penghargaan dapat dilihat dalam data berikut.

(5) $\mathrm{Hn}$

: pertanyaan Thamrin juga
sama jawabannya,
sekarang pertanyaan dari
Rs "kandungan apa yang
terkandung di kunyit putih
dan bisa mengurangi lemak
di perut?" karena
mengandung asam dan
mampu meningkatkan
metabolisme sehingga
mengakibatkan
pembakaran di sekitar
lemak.
: mana Riska
: jelas?
: jelas
: majasi
: thank you
: sama-sama

(No Data.31.02)

Konteks tuturan tersebut diucapkan oleh siswi berjenis kelamin perempuan yang sedang mengikuti proses pembelajaran di kelas XI IPS 2 dengan materi melaporkan hasil penelitian mata pelajaran bahasa Indonesia. Ketika itu Gs membantu Hn untuk menjelaskan bagaimana cara mengelola kunyit putih untuk pengobatan. Selama Hn menjelaskan dan dibantu oleh Gs, siswa bernama Tm tidak mendengarkannya, Gs langsung menegur Tm dengan kata-kata "baik pertanyaan berikutnya dengarin yaaa Thamri”. Hr memanggil Tm untuk mendengarkan jawaban yang dijelaskan oleh Hn dan Gs, kemudian Hn melanjutkan penjelasan dari pertanyaan An. Setelah Hn menjelaskan Hn bertanya kepada Ss "jelaskan" dan Ss menjawab "jelas" atas jawaban yang telah diberikan oleh Hn. Hn melanjutkan kembali untuk menjawab pertanyaan dari Tm dan Rs, pertanyaan Tm sama dengan pertanyaan yang ditanyakan oleh An, jadi Hn langsung menjelaskan pertanyaan dari Rs tentang " kandungan apa yang terkandung dikunyit putih dan bisa mengurangi lemak diperut?". Setelah Hn menjelaskan pertanyaan dari Rs, Gs mencari Rs "mana Riska", Rs mengangkat tangannya dan Hn langsung bertanya "jelas ?" Rs pun menjawab "jelas" atas jawaban yang diberikan oleh Hn untuknya. Gs mengucapkan "makasih" kepada Hn karena ia bisa menjelaskan pertanyaan dari teman-temannya, selain Gs Rs pun juga mengucapkan "terima kasih" kepada $\mathrm{Hn}$ dan Hn menjawab dengan "sama-sama".

Tuturan penutur Hn, lawan tutur Rs dan Gs menunjukkan proses komunikasi yang mematuhi maksim kedermawanan, maksim permufakatan, dan maksim penghargaan. Hal ini terdengar, pada tuturan Hn yang " jelas? " mematuhi maksim kedermawanan karena Hn memberikan kesempatan kepada lawan tutur Rs apakah tuturannya sudah jelas atau tidak, sedangkan tuturan Rs "jelas" termasuk dalam pematuhan maksim permufakatan karena antara penutur $\mathrm{Hn}$ dan lawan tutur Rs dapat saling membina kecocokan atau kemufakatan di dalam kegiatan bertutur, dan pada tuturan Gs dan Rs "makasih", thank you" termasuk dalam pematuhan maksim penghargaan karena Gs dan Rs dalam bertutur selalu berusaha memberikan penghargaan kepada pihak lain. Dalam maksim kedermawanan atau maksim kemurahan hati, para peserta pertuturan diharapkan dapat menghormati orang lain. Maksud dari maksim kedermawanan ini adalah menghendaki setiap peserta pertuturan untuk memaksimalkan kerugian diri sendiri dan meminimalkan keuntungan diri sendiri, sedangkan maksim permufakatan menekankan agar para peserta tutur dapat saling membina kecocokan atau kemufakatan di dalam kegiatan bertutur, dan maksim penghargaan dijelaskan bahwa orang akan 
dapat dianggap santun apabila dalam bertutur selalu berusaha memberikan penghargaan kepada pihak lain. Melalui tiga maksim ini, diharapkan agar para peserta pertuturan tidak saling mengejek, saling mencaci, atau saling merendahkan pihak lain. Selain itu, faktor penyebab kesantunan berbahasa ialah memberikan keuntungan pada mitra tutur karena memberikan kesempatan kepada lawan tutur untuk bertanya, serta memberikan pujian pada mitra tutur dalam kegiatan bertutur.

\section{KESIMPULAN}

Penyimpangan prinsip kesantunan dalam proses pembelajaran di kelas XI SMA N 9 Balikpapan berupa penyimpangan satu maksim dan dua maksim sebanyak (77 data). Dalam penyimpangan satu maksim yang paling dominan disimpang ialah maksim kebijaksanaan dengan (27 data) sedangkan dalam penyimpangan dua maksim yang paling dominan disimpang ialah maksim kebijaksanaan dan maksim kedermawanan yaitu (4 data). Dalam hal ini, penyimpangan kesantunan berbahasa paling banyak disimpang dalam proses pembelajaran, penyimpangan banyak terjadi pada saai diskusi dan sesi tanya jawab berlangsung dan hamper semua maksim disimpang oleh peserta didik selama proses pembelajaran berlangsung.

Selain itu, faktor yang mempengaruhi ketidaksantunan berbahasa paling dominan ialah faktor sengaja memojokkan mitra tuturnya dengan (57 data).

Pematuhan prinsip kesantunan dalam proses pembelajaran di kelas XI SMA N 9 Balikpapan berupa pematuhan satu maksim, dua maksim, dan tiga maksim sebanyak (8 data). Dalam pematuhan prinsip kesantunan berbahasa hanya ada tiga maksim saja yang terdapat dalam ketiga konteks yaitu, konteks sebelum proses pembelajaran, konteks diskusi, dan konteks sesi tanya jawab. Dari maksim-maksim tersebut, maksim yang paling banyak dipatuhi ialah maksim kebijaksanaan

dan

maksim

kedermawanan.

Pada maksim kebijaksanaan tersebut, faktor dominan penyebab kesantunan ialah memperhatikan cara menyampaikan dalam penggunaan ragam bahasa yang digunakan yaitu dengan menggunakan diksi yang halus seperti menggunakan kata "maaf" ketika terlambat masuk kelas sedangkan maksim kedermawanan. Faktor dominan penyebab kesantunan ialah memperhatikan pesan yang disampaikan dan tujuan yang hendak dicapai contohnya ketika penutur menanyakan kepada lawan tutur apakah penjelasannya telah dipahami, maka penyaji menanyakan dengan kata "ada yang mau bertanya?", "ya ... jelas tidak", dan "jelaskan ?" dengan nada bertanya. Berdasarkan konteks dalam proses pembelajaran, pematuhan prinsip kesantunan berbahasa paling banyak muncul pada konteks sesi tanya jawab.

\section{DAFTAR PUSTAKA}

Chaer, Abdul. 2010. Kesantunan Berbahasa. Jakarta : PT Rineka Cipta

Mahsun. 2005. Metode Penelitian Bahasa : Tahapan Strategi, Metode, dan Tekniknya. Jakarta : Raja Grafindo Persada.

Nathanael. 2013. Studi Karakter Siswa SLTA di Kota Medan. Journal Teknologi Pendidikan, 06 (1), 185196.

Oktaviana. 2012. Analisis Pemanfaatan Kesantunan Berbahasa Pada Kegiatan Diskusi Kelas Siswa Kelas XI SMA N 1 Sleman. Skripsi : Universitas Negeri Yogyakarta.

Rahardi, Kunjana. 2005. Pragmatik Kesantunan Imperatif Bahasa Indonesia. Jakarta : Erlangga. 
Retnowaty, R. (2015). Politeness

Strategies Used by Colter Stevens as the Main Character in Source Code Movie. In UNNES International Conference on ELTLT (English Language Teaching, Literature, and Translation) (pp. 696-708).

Riyanto, Udik. 2013. Realisasi Kesantunan Berbahasa Pada Percakapan Siswa dengan Guru di SMA Muhammadiyah 3 Surakarta. Journal Teknologi Pendidikan, 02 (1), $1-13$.

Rosanti, dkk. 2015. Realisasi Kesantunan Berbahasa Guru dan Siswa Kelas VII A SMP Negeri 2 Sungai Pinyuh.

Sugiyono. 2012. Metode Penelitian Pendidikan Pendekatan Kuantitatif, dan $R \& B$. Bandung :Alfabeta.

Umamah, Khorunnisa. 2015. Realisasi Kesantunan Berbahasa di Kalangan Santri Putri dalam Berinteraksi dengan Masyarakat Pesantren. 